\title{
Lahar Susceptibility of Magelang, Central Java after the 2010 Eruption of Merapi Volcano
}

\author{
Suprapto Dibyosaputro \\ Department of Environmental Geography \\ Faculty of Geography \\ Universitas Gadjah Mada \\ Yogyakarta, Indonesia \\ Corresponding email: supraptod@ugm.ac.id
}

\begin{abstract}
Since the major eruption in 1930 that caused more than 1,300 casualties, the eruptions of Merapi have caused many impacts to human lives. One of the effects caused by the eruption of Merapi Volcano is the lahar. This paper aims to discuss the lahar susceptibility in Magelang District, Central Java Province. The method used are literature study, analysis of secondary data such as a Rupa Bumi Map, high-resolution remote sensing image containing the image of the post-lahar flood and field surveys. The analysis showed that the Magelang district is an area that has a high susceptibility to lahar flood, particularly the region located around Pabelan River, the White River, River Krasak, Senowo River, River Tringsing and Sungai Batang. The most susceptible area is the area located above the bend simultaneously contained on the presence of break of slope, river channel narrowing, overflows on the outer banks of the river, river channel siltation and the confluence of two rivers where lahar flows.
\end{abstract}

\section{Keywords - Lahar, susceptibility, Merapi Volcano, Magelang}

\section{INTRODUCTION}

Since the major eruption in 1930 that caused more than 1,300 casualties, the eruptions of Merapi have caused fewer physical, demographic, economic, and environmental impacts (Voight et al., 2000). However, the 2010 eruption showed greater activities and larger impacts than those of the previous eruptions. On October 26, 2010 Merapi erupted eight times and produced pyroclastic materials as well as pyroclastic flows (nuée ardentes) that reached a distance of $15 \mathrm{~km}$ from the top of the volcano and claimed 135 deaths. Their sound was heard up to $30 \mathrm{~km}$ away and 150 million $\mathrm{m}^{3}$ of pyroclastic materials were released. The 2010 eruption also made the greatest record in history due to the necessary evacuation of 320,000 people to temporary shelters. The volcanic ash vastly covered the cities lying from the west side of Merapi to the west part of Java Island, i.e. Bogor and Bandung. It delayed the flights that pass over Yogyakarta. In addition to its adverse impacts, it might lead to respiratory problems and increase the risk of bronchitis and asthma (Horwell and Baxter, 2006). At the same time, its environmental and infrastructural impacts included damages to 867 ha of forest, or equal to a loss of IDR 33 billion, in Sleman Regency, springs and pipelines, and roads and bridges as well as disruptions to economic activities.

The eruption of Merapi poses not only primary hazards, i.e. pyroclastic flows and volcanic ash, but also secondary hazards, i.e. post-eruption lahars that last as long as the length of the following rainy seasons (Lavigne et al., 2000). A mixture of boulders, rocky debris, pebbles, sands, and silts, which are controlled by gravitational force, and post-eruption volcanic materials is the composition of lahars (Smith and Fritz, 1989). Therefore, lahars will continue to persist until the 150 billion $\mathrm{m}^{3}$ of post-eruption materials are exhausted. In certain circumstances, they are more destructive than pyroclastic flows (Wood and Soulard, 2009; Gomez et al., 2009).

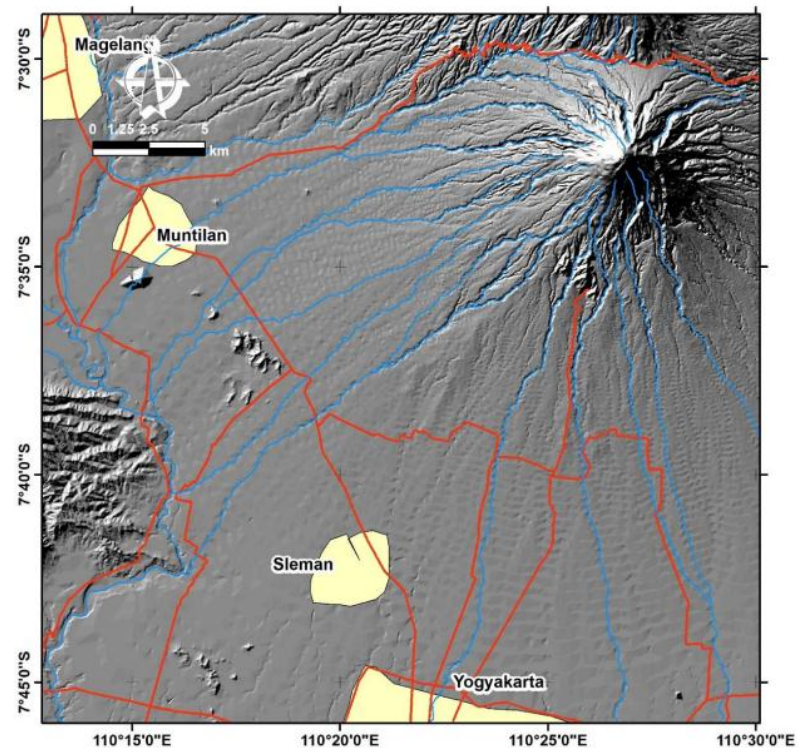

Fig. 1. The location of Merapi, surrounded by Muntilan, Sleman, and Yogyakarta

During the eruption phase on December 13, 1930 and January 7-8, 1969, lahars flowed along nine rivers between 
Pabelan and Woro (Lavigne et al., 2000). The mean frequency of this type of lahar is once in 30 years. Meanwhile, the posteruption lahars occur annually along the rivers whose upper streams flow from Merapi (Lavigne et al., 2000). These rivers, namely Pabelan, Putih, Gendol-Opak, Boyong-Code, Krasak, Woro, and Kuning River, potentially transport lahars and their destructive nature downstream.

Therefore, people residing in the middle and lower area of these rivers are vulnerable to the impacts of lahars (Vallance, 2000). Unfortunately, they generally lack awareness of the potential threats of the place they live in (Crandell et al., 1984). Damages and losses caused by lahars are larger in the presence of high-risk elements, as the combination of high vulnerability and low capacity (Dibben and Chester, 1999).

\section{METHOD}

The identification of lahar susceptibility done by analyzing the impact as well as morphological characteristic of the river within Magelang regency. This study is based on a combination of secondary data and primary data analysis to identify the lahar of Merapi. These draw on four technical approach such as literature study, analysis of secondary data (Rupa Bumi Map, high-resolution remote sensing image containing the image of the post-lahar flood) and field surveys.

During field survey, five study sites were equipped in order to evaluate the morph dynamic process. We conduct topographic survey and identification of sedimentation facies of volcanic materials to show the footprints of lahars in the past and in the present. In addition, we analyses the presence of break of slope, river channel siltation and erosion in the river to get the description of morphological characteristic.

\section{FINDING AND DISCUSSION}

\section{A. Lahar Susceptibility in Magelang Regency}

Magelang Regency is located on the west slope of Merapi and is potentially threatened by either primary or secondary hazards. The long-standing primary hazard is pyroclastic flow, which has been occurring in Magelang Regency for several times, as seen in Figure 2.

Magelang is one of many regencies that were devastated by the post-eruption lahars in 2010. The most inundated areas of lahars were found in the break of slope and in a gently sloping area. Lahars flow along the rivers through densely populated area, viz. Pabelan River flowing through Muntilan and Yogyakarta-Semarang roadway, Putih River flowing through Muntilan, and Krasak River flowing through the main access between Magelang and Yogyakarta. On Sunday afternoon (April 3, 2011), they overflowed Pabelan River, enabling the bridge that connects Yogyakarta and Semarang (Indosiar,
Sunday, April 3, 2011). Furthermore, on Wednesday, December 1, 2012, they destroyed four infrastructures, i.e. a bridge in Gondowangi Village (Sawangan), Kojor Bridge in Bojong (Mungkid), Semendi Dam in Gunung Lemah (Gondowangi, Sawangan), and Srowol Bridge (Suaramerdeka.com, Thursday, December 2, 2012).

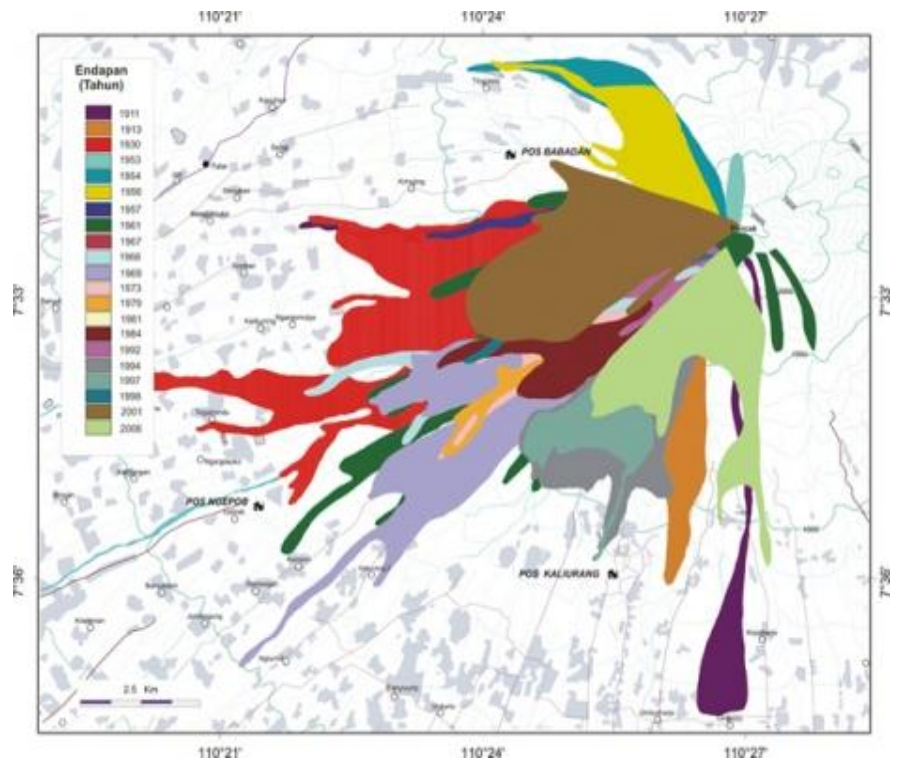

Fig. 2. The spatial and temporal distribution of pyroclastic flows on the slopes of Merapi (Brontopuspito et al., 2012)

Magelang Regency also suffers from the secondary hazards of Merapi, i.e. lahars. Lahars caused a vast damage in the regency after the eruptions in 1822, 1872, 1930, 1931, 1960, 1991, 1969, 1971 and 2010 (Murwanto et al., 2013). The distribution map of the impacts of lahars in the study area is presented in Figure 3. In line with the study conducted by Brontopuspito et al. (2012), the lahars of Merapi mostly occur in and, thereby, majorly affect Magelang and Sleman Regency (Figure 4).

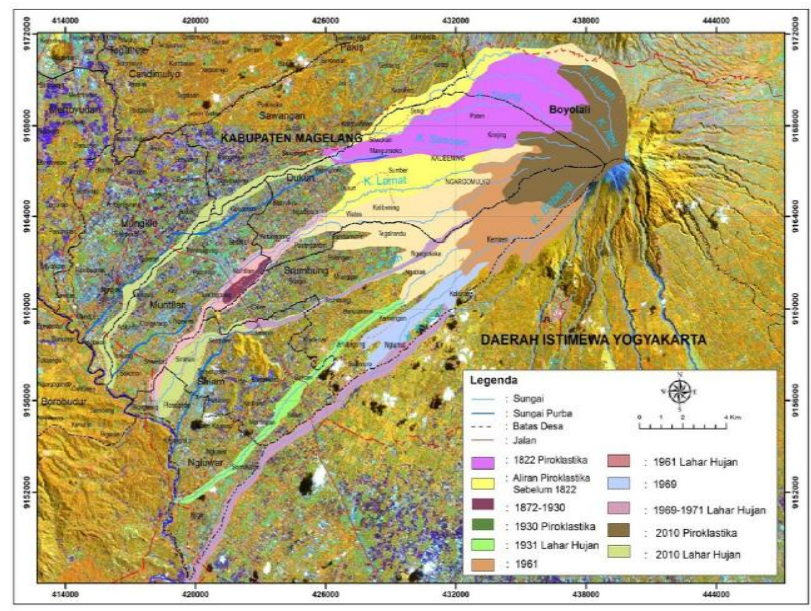

Fig. 3. The map of lahar-affected area in Magelang Regency within the year of 1822-2015 (Murwanto et al., 2013) 
Lahars, as disasters that have happened many times, led to morphological changes in river channels. The condition increases the lahar susceptibility of not only areas along the current rivers but also potentially, in the future, to other areas due to the shifts of the river channels. Therefore, this study mapped lahar susceptibility based on the sedimentation facies of volcanic materials that are able to show the footprints of lahars in the past and in the present. Several examples of the footprints in the past are presented in Figure 5-7.

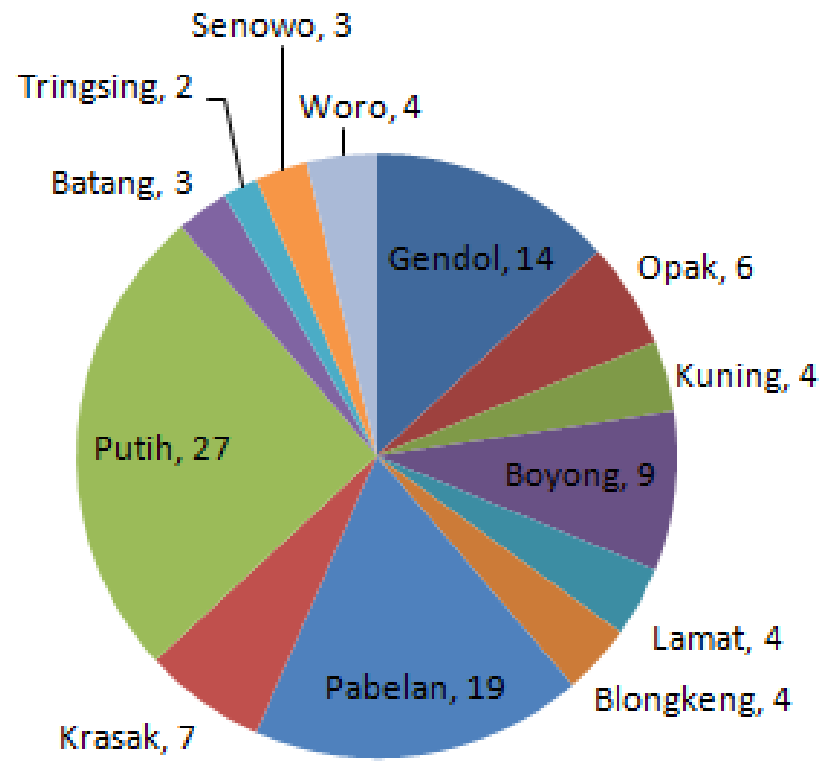

Fig. 4. The number of post-eruption lahar events in 2010 (Brontopuspito et al., 2012)

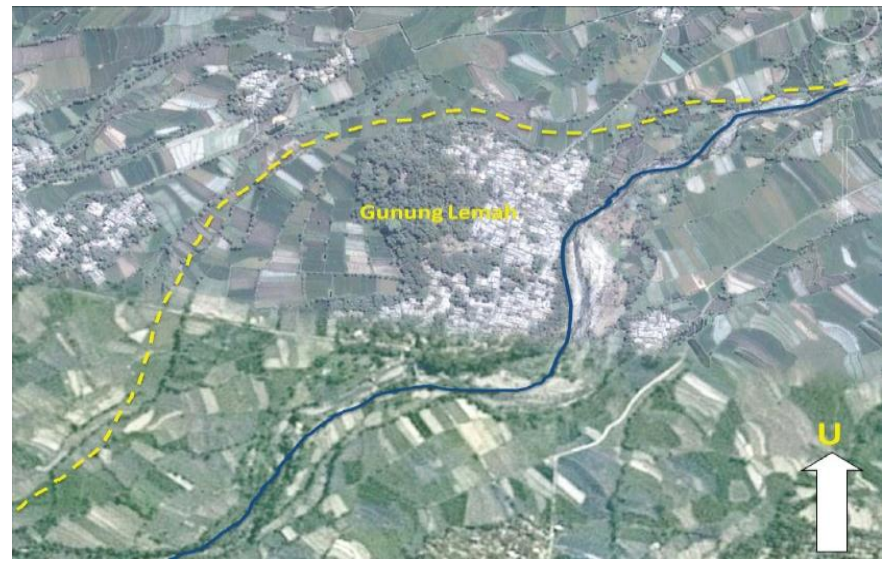

Fig. 5. The appearance of the old channel (yellow) and new channel (blue) of Pabelan River (Murwanto et al., 2013)

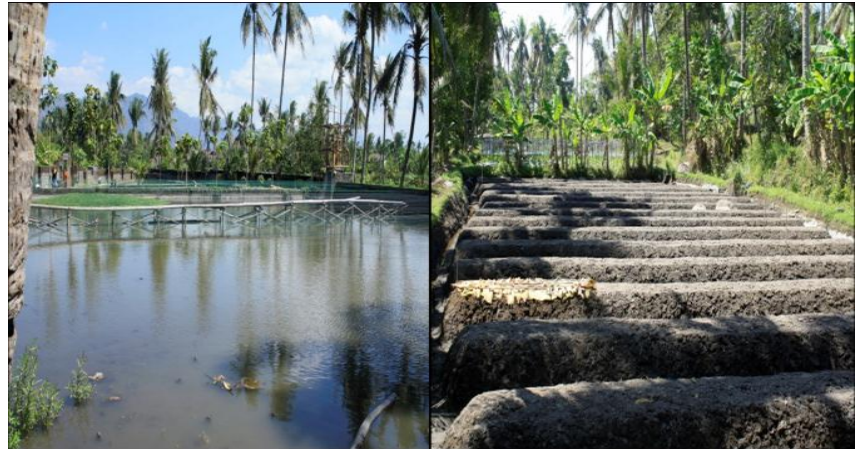

Fig. 6. Land utilization on the abandoned channel of Pabelan River (Murwanto et al., 2013)

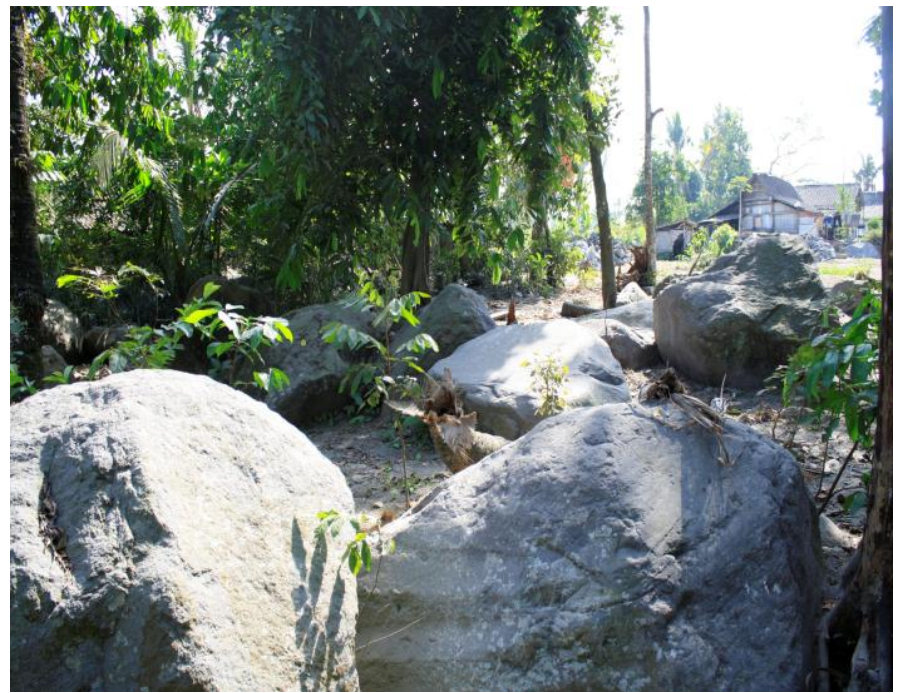

Fig. 7. The composing materials of lahars deposited in a settlement far from the current river channel

Based on the data and field survey, area that has a high susceptibility to lahar flood is the region located around Pabelan River, the White River, River Krasak, Senowo River, River Tringsing and Sungai Batang. The most susceptible area is the area located above the bend simultaneously contained on the presence of break of slope, river channel narrowing, overflows on the outer banks of the river, river channel siltation and the confluence of two rivers where lahar flows.

\section{CONCLUSIONS AND SUGGESTIONS}

The results of analysis on previous studies and field observations as well as damage mapping in several areas in Magelang Regency show that the spatial pattern of damage caused by lahars to various at-risk elements, such as settlement, infrastructure, and agricultural field, is controlled by the morphological characteristics of the rivers. The characteristics that lead to this damage pattern are as follows:

- The presence of break of slope

- River channel narrowing

- Overflows on the outer banks of the river

- River channel siltation 
- The confluence of two rivers where lahar flows

Therefore, the future development of land utilization within the spatial proximity of these characteristics requires careful consideration particularly due to the potential damages, losses, and casualties caused by major lahars.

\section{ACKNOWLEDGMENT}

This research is part of a research grant offered by the Higher Education Prime Research (Penelitian Unggulan Perguruan Tinggi-PUPT) of the Indonesian Ministry of Research, Technology and Higher Education (Kementerian Riset, Teknologi dan Pendidikan Tinggi-Kemenristekdikti) in 2016 titled "The Integration of Disaster Studies to Promote Regional Development Planning and Society Capacity Building in Merapi Hazard Zones (Integrasi Kajian Kebencanaan untuk Mendukung Perencanaan Pengembangan Wilayah dan Peningkatan Kapasitas Masyarakat Pada Kawasan Rawan Bencana Gunungapi)" with a contract number 679/UN1-P.III/LT/DIT-LIT/2016.

\section{REFERENCES}

[1] Brontopuspito, K; Suratman; Pramumijoyo, S.; Hadmoko, D.S. Harijoko, A. and Suyanto, W. 2012. Kajian Multi-Bahaya, Kerentanan, Risiko, Desain Tata Ruang Kawasan Rawan Bencana Merapi dan Implementasinya dalam Peningkatan Kapasitas Dan Kesiapsiagaan Masyarakat Terhadap Bahaya Gunungapi. Laporan Penelitian Hibah Strategis Nasional. LPPM Universitas Gadjah Mada.

[2] Crandell D.R.; Booth B.; Kusumadinata K.; Shimozuru, D.; Walker, G.P.L.; and Westercamp D. 1984. Source-book for volcanic-hazards zonation. UNESCO, Paris.

[3] Dibben, C. dan Chester, D.K. 1999. Human vulnerability in volcanic environments: the case of Furnas, Sao Miguel, Azores. Journal of Volcanology and Geothermal Research 921999 133-150.

[4] Gomez, C.; Lavigne, F. and Hadmoko, D.S. 2009. Lahars Deposits Architecture and Volume in the C. Lengkong Valley at Semeru Volcano, Indonesia.

H.A.L. http://hal.archivesouvertes.fr/docs/00/37/83/15/PDF/GOMEZ_Lahars_ Deposits_Architecture_nd_Volume.pdf

[5] Horwell, C.J. and Bazter, P.J. 2006. The respiratory health hazards of volcanic ash: a review for volcanic risk mitigation. Bulletin of Volcanology 69: 1-24

[6] Lavigne, F.; Thouret, J.C.; Suwa, H.; Voight, B.; Young, K.; Lahusen, R.; Marso, J.; Sumaryono, A.; Dejean, M.; Sayudi, D.S. and Moch. 2000. Instrumental Lahar Monitoring at Merapi Volcano, Central Java, Indonesia. Journal of Volcanology and Geothermal Research, 100: 457 478 .
[7] Murwanto, H.; Siregar, D.A.; and Purwoarminta, A. 2013. Jejak Erupsi Gunung Merapi di Kabupaten Magelang Provinsi Jawa Tengah. Jurnal Lingkungan dan Bencana Geologi, 4(2): 135 - 147.

[8] Smith, G.A. and Fritz, W.J. 1989. Penrose Conference report: Volcanic influences on terrestrial sedimentation. Geology 17: 376.

[9] Vallance, J.W. 2000. Lahars, In Sigurdsson, H.; Houghton, B.F.; Mc. Nutt; S. Rymer; H.Stix, J. eds, Encyclopedia of volcanoes. San Diego: Academic Press, p 601-616.

[10] Voight, B.; Constantine, E.K.; Siswowidjoyo, S.; and Torley, R. 2000. Historical eruptions of Merapi Volcano, Central Java, Indonesia, 17681998. Journal of Volcanology and Geothermal Research 100: 69-138

[11] Wood, N. and Soulard, C. 2009. Community exposure to lahar hazards from Mount Rainier, Washington: U.S. Geological Survey Scientific Investigations Report 2009-5211, 26 p. 